\title{
"A study to assess the effectiveness of structured teaching programme on knowledge of adolescents (age group 16-18 years) regarding selected aspects of women empowerment at selected $P$ U College, Nagamangala Taluk, Mandya District."
}

\author{
Vincent Patil \\ Lecturer \\ Dept of Community Health Nursing, St Ignatius Institute Of Health Sciences, Honavar, Karnataka, India \\ Rajiv Gandhi University Of Health sciences, Bangaluru, Karnataka, India
}

\begin{abstract}
Around 35(58\%) of students belong to the age of 16 years, $15(25 \%)$ were in the age of 17 years, $10(17 \%)$ were in the age of 18 years. Around 24(40\%) were males and 36(60\%) were females. Majority of the $45(75 \%)$ were living in rural areas and $15(25 \%)$ were living in urban areas. Majority of the $48(80 \%)$ were Hindu, 8(13\%) were Muslims, 03(5.0\%) were Christian and 1(1.67\%) are any others. Majority of were 44(73\%) had income between Rs.5001-10000, 8(13\%) had income between Rs.10001-15000, 5(8\%) had income above Rs. 15000 and 03(5\%) had income below Rs.5000. Majority 37(61.67\%) were belongs to arts, 17(28\%) were belongs to science and 6(10\%) were belongs to commerce. Majority 48(80\%) were belongs to Kannada medium and 12(20\%) were belongs to English medium. Majority of students 34(57\%) reported print media as the major source of information, followed by 14(23\%) reported electronic media, 5(8\%) had health professionals, 4(7\%) had friends and relatives and 3(5\%) had family members as the source of information. The mean difference between the mean pre-test and mean post-test knowledge score was subjected to Paired ' $t$ ' test and the value of ' $t$ '(59) $=1.67$, was found significant at 0.05 levels and it was inferred that the posttest knowledge score of selected adolescents of age 16-18 years of selected $P U$ College after structured teaching Programme was significantly higher than their mean pretest knowledge scores. The computed chi-square values for association between pretest level of knowledge of selected adolescents of age group 16-18 years of selected P U College regarding selected aspects of women empowerment and their selected demographic variables are age and source of information found to be statistically significant and other variables like gender, type of community, religion, type of family, monthly income of family, stream of education combination, medium of instruction are not found statistically significant.
\end{abstract}

Keywords: women empowerment, female birth, female education, women security, structured teaching.

\section{Introduction}

Women empowerment is a new phrase in the vocabulary of gender literature. The phrase is used in two broad senses i.e. general and specific. In a general sense, it refers to empowering women to be self-dependent by providing them access to all the freedoms and opportunities, which they were denied in the past only because of their being women. In a specific sense, women empowerment refers to enhancing their positioning the power structure of the society. The word women empowerment essentially means that the women have the power or capacity to regulate their day- to- day lives in the social, political and economic terms -a power which enables them to move from the periphery to the centre stage.

Each year we celebrate International Women's day on March $8^{\text {th }}$ with a determination to commemorate the achievements of women, and to acknowledge the special status they deserve in society. The significant question is what difference has it made to the position of women? Have women become really strong, and have their long term Struggles ended? Though women have progressed in a number of spheres, yet looking from a wider perspective, the situation remains grim. According to the statistics by CARE, out of 1.3 billion people who live in absolute poverty around the globe, $70 \%$ are women. Reflecting on UNESCO's medium term strategy 2008-13, gender equality has been assigned as Organization's global priority. Astonishingly, two third of the 774 million adults in the world who cannot read is women. ${ }^{1}$

Empowerment of women needs to begin with her participation in different spheres of life. Birth education is a great determin ant in this regard. To achieve empowerment women have to be educated to be aware of their rights and privileges in a modern society. It is education which can bring about awareness in them related to their social status, injustice and differentiation meted out to them. Besides, economic independence is a major factor which can contribute in empowering women. India in the very beginning realized this need. 


\section{Methodology}

The research design selected for the study was quasi experimental with one group pre- test and posttest design, in which pre- test is conducted followed by structured teaching programme and then post- test was conducted on $8^{\text {th }}$ day after structured teaching programme for the same group

\section{The objectives of the study were:}

1) To assess the pre-test level of knowledge in adolescents regarding selected aspects of women empowerment in selected P U College.

2) To assess post-test level of knowledge in adolescents regarding selected aspects of women empowerment in selected P U College.

3) To evaluate the effectiveness of structured teaching programme.

4) To find the association between the pre-test level of knowledge scores among adolescence with selected socio demographic variables.

\section{Results}

Section 1: Description of Selected Demographic Variables.

Frequency and percentage distribution of selected adolescents of P U College according to their Selected Demographic Variables.

Section-2: Analysis of overall and aspect wise knowledge scores of respondents on selected aspects of women empowerment.

Section 3: Findings related to association of levels of knowledge of selected P U College adolescents with their selected demographic variables viz. age, gender, type of community, religion, monthly income of family, stream of education, level of education, source of information.

\section{Section 1}

Description Of Selected Demographic Variables

A. Frequency and percentage distribution of adolescents of $P$ U College in experimental group according to their Selected Personal Variables.

TABLE-1

Frequency and percentage distribution of selected $P$ U adolescents according to their demographic variables $\quad \mathrm{N}=\mathbf{6 0}$

\begin{tabular}{|c|c|c|c|}
\hline $\begin{array}{l}\text { Sl. } \\
\text { No }\end{array}$ & Demographic variables & Frequency (f) & Percentage $(\%)$ \\
\hline \multirow[t]{4}{*}{1.} & Age (in years) & & \\
\hline & a) $16 \mathrm{yrs}$ & 35 & 58 \\
\hline & b) $17 \mathrm{yrs}$ & 15 & 25 \\
\hline & c) $18 \mathrm{yrs}$ & 10 & 17 \\
\hline \multirow[t]{3}{*}{2.} & Gender & & \\
\hline & Male & 24 & 40 \\
\hline & Female & 36 & 60 \\
\hline \multirow[t]{3}{*}{3.} & Type of community & & \\
\hline & Rural & 45 & 75 \\
\hline & Urban & 15 & 25 \\
\hline \multirow[t]{5}{*}{4.} & Religion & & \\
\hline & Hindu & 48 & 80 \\
\hline & Muslim & 8 & 13 \\
\hline & Christian & 3 & 5.00 \\
\hline & Any others & 1 & 1.67 \\
\hline \multirow[t]{5}{*}{5.} & Monthly income of family & & \\
\hline & Below 5000 & 3 & 5 \\
\hline & $5000-10000$ & 44 & 73 \\
\hline & $10000-15000$ & 8 & 13 \\
\hline & Above 15000 & 5 & 8 \\
\hline \multirow[t]{4}{*}{6.} & Stream of $P$ U combination & & \\
\hline & Science & 17 & 28 \\
\hline & Arts & 37 & 61.67 \\
\hline & Commerce & 6 & 10.00 \\
\hline \multirow[t]{3}{*}{7.} & & & \\
\hline & Kannada & 48 & 80 \\
\hline & English & 12 & 20 \\
\hline
\end{tabular}


"A study to assess the effectiveness of structured teaching programme on knowledge of adolescents

\begin{tabular}{|c|c|c|c|}
\hline \multirow[t]{5}{*}{8.} & Source of information & & \\
\hline & Print media & 34 & 57 \\
\hline & Electronic media & 14 & 23 \\
\hline & Health professionals & 5 & 8 \\
\hline & Friends or neighbours & 4 & 7 \\
\hline
\end{tabular}

Section-2: Analysis of overall and aspect wise knowledge scores of P U students on selected aspects women empowerment

\begin{tabular}{|c|c|c|c|c|c|c|}
\hline \multirow{3}{*}{ No. } & \multirow{3}{*}{ Knowledge Aspects } & & & & $\mathrm{N}=6$ & \\
\hline & & \multirow{2}{*}{ Statements } & \multirow{2}{*}{$\begin{array}{l}\text { Max. } \\
\text { Score }\end{array}$} & \multicolumn{3}{|c|}{$\begin{array}{c}\text { Pre-test Knowledge mean scores of } \\
\text { selected P U College adolescents }\end{array}$} \\
\hline & & & & Mean & SD & $\begin{array}{c}\text { Mean } \\
(\%)\end{array}$ \\
\hline I & $\begin{array}{l}\text { General Information on women } \\
\text { empowerment }\end{array}$ & 5 & 5 & 2.9 & 0.8 & 58.0 \\
\hline II & Information regarding female birth & 10 & 10 & 5.0 & 1.4 & 49.5 \\
\hline III & $\begin{array}{l}\text { Information regarding female } \\
\text { education }\end{array}$ & 10 & 10 & 5.6 & 1.1 & 55.5 \\
\hline IV & $\begin{array}{l}\text { Information regarding women } \\
\text { security. }\end{array}$ & 03 & 03 & 1.7 & 0.8 & 55.6 \\
\hline \multirow[t]{2}{*}{$\mathrm{V}$} & $\begin{array}{l}\text { Modes and methods of women } \\
\text { empowerment }\end{array}$ & 02 & 02 & 1.2 & 0.6 & 60.0 \\
\hline & Over all & 30 & 30 & 16.26 & 3.03 & 53.90 \\
\hline
\end{tabular}

Table 2: Aspect wise Pretest Mean Knowledge scores of selected P U adolescents on selected aspects of women empowerment

\section{SECTION 3}

TABLE 3

Association of pre-test level knowledge of selected adolescents of age group 16-18yrs regarding selected aspects of women empowerment with their selected demographic variables of students viz. age, gender, type of community, religion, monthly income of family, stream of education, level of education, source of information

$\mathrm{n}=60$

\begin{tabular}{|c|c|c|c|c|c|c|c|c|c|c|}
\hline \multirow{3}{*}{$\begin{array}{l}\text { Sl. } \\
\text { No }\end{array}$} & \multirow{3}{*}{ Demographic variables } & \multirow{2}{*}{\multicolumn{2}{|c|}{ Sample(n) }} & \multicolumn{4}{|c|}{ knowledge level of Respondents } & \multirow{3}{*}{ d.f } & \multirow{3}{*}{$\begin{array}{c}\text { Chi } \\
\text { square } \\
(\chi 2- \\
\text { value }) \\
\end{array}$} & \multirow{2}{*}{$\begin{array}{c}\text { Significanc } \\
\text { e } \\
\text { at } 0.05 \\
\text { level }\end{array}$} \\
\hline & & & & \multicolumn{2}{|c|}{$\begin{array}{l}\square \text { median } \\
\text { (34) }\end{array}$} & \multicolumn{2}{|c|}{$\begin{array}{c}>\text { median } \\
(26)\end{array}$} & & & \\
\hline & & $\mathbf{N}$ & $\%$ & $\mathbf{F}$ & $\%$ & $\mathbf{f}$ & $\%$ & & & \\
\hline \multirow[t]{4}{*}{1.} & Age (in years) & & & & & & & & & \\
\hline & 16 years & 35 & 58 & 30 & 88.24 & 5 & 19.23 & \multirow{3}{*}{7} & \multirow{3}{*}{23.39} & \multirow{3}{*}{$\begin{array}{c}\mathrm{S}^{*} \\
\mathrm{P}<0.05\end{array}$} \\
\hline & 17 years & 15 & 25 & 3 & 8.82 & 12 & 46.15 & & & \\
\hline & 18 years & 10 & 17 & 1 & 2.94 & 9 & 34.61 & & & \\
\hline \multirow[t]{3}{*}{2.} & Gender & & & & & & & \multirow[b]{3}{*}{3} & \multirow[b]{3}{*}{0.72} & \multirow{3}{*}{$\begin{array}{c}\text { N.S } \\
\mathrm{P}>0.05\end{array}$} \\
\hline & Male & 24 & 40 & 12 & 35.29 & 12 & 46.15 & & & \\
\hline & Female & 36 & 60 & 22 & 64.71 & 14 & 53.85 & & & \\
\hline \multirow[t]{3}{*}{3.} & Type of community & & & & & & & \multirow[b]{3}{*}{3} & & \multirow[b]{3}{*}{$\begin{array}{l}\mathrm{NS} \\
\quad \mathrm{p}>0.05\end{array}$} \\
\hline & Rural & 45 & 75 & 25 & 73.53 & 20 & 76.29 & & & \\
\hline & Urban & 15 & 25 & 9 & 26.47 & 6 & 23.08 & & 0.09 & \\
\hline \multirow[t]{5}{*}{4.} & Religion & & & & & & & \multirow{5}{*}{7} & \multirow{5}{*}{2.39} & \multirow{5}{*}{$\begin{array}{c}\mathrm{NS} \\
\mathrm{p}>0.05\end{array}$} \\
\hline & Hindu & 48 & 80 & 25 & 75.53 & 23 & 88.46 & & & \\
\hline & Muslim & 8 & 13 & 6 & 17.63 & 2 & 7.69 & & & \\
\hline & Christian & 3 & 5.00 & 2 & 5.88 & 1 & 3.85 & & & \\
\hline & Any others & 1 & 1.67 & 1 & 2.94 & 0 & 0.0 & & & \\
\hline
\end{tabular}




\begin{tabular}{|c|c|c|c|c|c|c|c|c|c|c|}
\hline \multirow[t]{5}{*}{5.} & $\begin{array}{l}\text { Monthly income of } \\
\text { family (in rupees) }\end{array}$ & & & & & & & \multirow{5}{*}{7} & \multirow{5}{*}{4.83} & \multirow{5}{*}{$\begin{array}{c}\mathrm{NS} \\
\mathrm{p}>0.05\end{array}$} \\
\hline & Below 5000 & 3 & 5 & 2 & 5.88 & 1 & 3.85 & & & \\
\hline & $5001-10000$ & 44 & 73 & 28 & 82.35 & 16 & 61.54 & & & \\
\hline & $10001-15000$ & 8 & 13 & 2 & 5.88 & 6 & 23.08 & & & \\
\hline & 15001Above 15000 & 5 & 8 & 2 & 5.88 & 3 & 11.54 & & & \\
\hline \multirow[t]{4}{*}{6.} & $\begin{array}{l}\text { Stream of combination } \\
\text { education in } P U\end{array}$ & & & & & & & \multirow{4}{*}{5} & \multirow{4}{*}{1.88} & \multirow{4}{*}{$\begin{array}{c}\text { N.S } \\
\mathrm{p}>0.05\end{array}$} \\
\hline & Arts & 17 & 28 & 12 & 35.29 & 5 & 19.23 & & & \\
\hline & Science & 37 & 61.67 & 19 & 55.88 & 18 & 69.23 & & & \\
\hline & Commerce & 6 & 10.00 & 3 & 8.82 & 3 & 11.54 & & & \\
\hline \multirow[t]{3}{*}{7.} & $\begin{array}{l}\text { Medium of instruction } \\
\text { studied in SSLC }\end{array}$ & & & & & & & \multirow{3}{*}{3} & \multirow{3}{*}{3.32} & \multirow{3}{*}{$\begin{array}{c}\mathrm{NS} \\
\mathrm{p}>0.05\end{array}$} \\
\hline & Kannada & 48 & 80 & 30 & 88.24 & 18 & 69.23 & & & \\
\hline & English & 12 & 20 & 4 & 11.76 & 8 & 30.77 & & & \\
\hline \multirow[t]{6}{*}{8.} & $\begin{array}{l}\text { Source of information } \\
\text { about selected aspects of } \\
\text { women empowerment }\end{array}$ & & & & & & & \multirow{6}{*}{9} & \multirow{6}{*}{23.86} & \multirow{6}{*}{$\begin{array}{c}\mathrm{S}^{*} \\
\mathrm{P}<0.05\end{array}$} \\
\hline & Print media & 20 & 33 & 12 & 35.29 & 8 & 30.77 & & & \\
\hline & Electronic media & 25 & 42 & 16 & 47.06 & 9 & 34.62 & & & \\
\hline & Health professional & 5 & 8 & 3 & 8.82 & 2 & 7.69 & & & \\
\hline & $\begin{array}{l}\text { Family members or } \\
\text { relatives }\end{array}$ & 4 & 7 & 1 & 2.94 & 3 & 11.54 & & & \\
\hline & Friends or neighbours & 6 & 10 & 2 & 5.88 & 4 & 15.38 & & & \\
\hline
\end{tabular}

\section{Conclusion}

The findings reveals that maximum participants 19 (31.67) had inadequate knowledge in pre-test and majority of participants 17 (28.33) had adequate knowledge in post test and concluded that there was a significant improvement in the level of knowledge regarding selected aspects of women empowerment in post test after administration of structured teaching program. Thus, structured teaching programme was found to be effective in improving the knowledge regarding selected aspects of women empowerment in selected adolescents of selected P U College.

Among the demographic variables analyzed in the study, age and source of information had found to have significant association with knowledge scores. And there was no significant association found between gender, type of community, religion, stream of education combination, medium of instruction studied in SSLC and monthly income of family with knowledge scores among the adolescents of age group 16-18 years of selected P U College.

\section{Implication for nursing education:}

Preparing structured teaching programme must be emphasized in the nursing curriculum. So that the nursing students will gain more knowledge in depth regarding women empowerment and its importance on health which helps to educate the youths regarding female birth, education and security there by reducing the complication in future and improve the abilities of the students to conduct the health education programmes.

\section{Implication for community health practice:}

Community health nurse should plan and organize continuing education program and prepare STP for community nurses and other cadre of community health personals like male and female health workers, lady health visitors, health supervisors, local leaders, mahilamandals and also ASHA's to motivate them in conducting teaching programme on selected aspects of women empowerment.

\section{Implication for nursing research:}

Various studies conducted by researchers showed that women empowerment affects the community and prevent many health problems in community. For this reason awareness creation is a key measure to address the impact of community change on health and environment. So studies should be carried out and mainly focusing on the knowledge regarding selected aspects of women empowerment

\section{Bibliography}

[1]. Introduction to women empowerment available from:www.wikipedia.org/womenempowerment

[2]. Patel. V. And kumar. H. Declining sex ratio and reproductive technology. Health action 2010 Aug.: 16 (9) $62-75$.

[3]. Singh. R. and Manu.J.current status of women in Indian society 2010. Mar: 20 (11) 12-21.

[4]. Dr.Vibhuthi Patel and Safat. R. The unwelcome sex female foeticide in India. World health forum 2000: 11: 309.

[5]. National survey and research centre, India. Report on women in India 2010. Mar (5) 65-74.

[6]. Shewta. P. female foeticide. A study of Karnataka DCWC research bulletin 2011jul-sep: 9-15.

[7]. Allahabad research Centre, University of medical sciences. Uttar Pradesh. Declining women strength leading to poverty. 2011 
[8]. Dr Rajana, Kumara.ViolenceAgainst the Girl Child. Health action 2011 Jan 17 (1)

[9]. India together: A cultural deficit (citied 2010) June 5 (4 screens)

[10]. Anne Marie and RinaSen Gupta, (2011), "Who takes the credit? Gender, Power, and Control over Loan Use in Rural Credit Programs in Tamil Nadu." World Development 24(1), pp. 45-63. 